Katarzyna Szalewska

Wydział Filologiczny

Uniwersytet Gdański

e-mail: k.szalewska@ug.edu.pl

\title{
Figury nieobecności / Retoryka pustki
}

Za każdym razem, gdy mowa jest w polskim dyskursie literackim o procesach utekstawiania przestrzeni, trudno nie zauważyć, że tym, co najczęściej owej tekstualizacji podlega, są miejsca w sensie rzeczywistym nieistniejące. Klasyfikacja rodzimych pustek, białych punktów na mapach, mogłaby ciągnąć się w nieskończoność, wszak zaliczyć by tu trzeba i miejsca już nieobecne, lecz przywoływane do życia poprzez mit; i miejsca nigdy nieistniejące, tylko konstruowane ze słów i stojących za nimi wyobrażeń spacjalnych. Takimi Atlantydami byłyby więc i Kresy, i Galicja, ale także sielski Lwów, wielokulturowy Gdańsk czy przedwojenna Warszawa, wreszcie status ten przypadłby kreowanym we wspomnieniu przestrzeniom dziecinstwa czy budowanym za pomocą kulturowych kliszy obrazom polskiej wsi. Można więc uznać, że przywołane hasło obejmuje zbyt szerokie tekstowe obszary, a sama opozycja między miejscem istniejącym a nieistniejącym jest wątpliwa, co musi prowadzić do dość oczywistego wniosku, że wszystkie literackie przestrzenie cechuje widmowy, ściśle dyskursywny status ontologiczny. Wówczas proces utekstawiania miejsca poprzez literaturę wiązałby się przede wszystkim z performatywnym wymiarem pisma, które wypełnia kartograficzną pustkę (i w tym wypełnianiu wytwarza przestrzeń, wprowadza ją w sieć kulturowych zależności itd.).

Miejsca nieistniejące $\mathrm{w}$ polskiej literaturze podzielić można - w bardzo schematycznej i stanowiącej ledwie pierwszy szkic ujęcia tego wieloaspektowego problemu - klasyfikacji kategorii na kilka typów. Byłaby to propo- 
zycja dopełniająca istniejącą typologię miejsc autobiograficznych autorstwa Małgorzaty Czermińskiej ${ }^{1}$, a jednocześnie będąca jej odwróceniem. Miejsca nieistniejące bowiem to miejsca autobiograficzne à rebours, czyli takie, których właśnie podmiot nie zamieszkiwał, nie odwiedzał, które nie stanowiły tła dla jego życiowych doświadczeń. W tym apofatycznym ujęciu są one negatywem biograficznych przestrzeni twórców. Jednocześnie jednak trudno uznać, że miejsca nieistniejące na owe doświadczenie i pisarstwo nie wpływają. Rzecz ma się zgoła odwrotnie, a w wielu przypadkach uznać wręcz można, że ich wpływ jest silniejszy niż rzeczywistych przestrzeni. I nie jest to jedyny paradoks, który określa niejasną ontologię nieistniejących miejsc, do czego jeszcze wypadnie powrócić. Projektowana klasyfikacja musiałaby zatem zawierać miejsca opuszczone w wyniku świadomych decyzji podmiotu, których liczne przykłady znaleźć można w literaturze emigracyjnej. Należy je jednak wyraźnie odróżnić od miejsc utraconych - czyli tych opuszczonych w wyniku powojennych podziałów politycznych, inne jest bowiem zabarwienie emocjonalne opisujących je tekstów, inna poetyka zastosowana do ich literackiego wskrzeszenia, inna wreszcie ich dyskursywna egzystencja miasta opuszczone żyją we wspomnieniu, miasta utracone - w micie. Nieistnienie dotyka również miejsc dzieciństwa, które jednocześnie powołuje do fantazmatycznego życia, ale uśmierca w sensie rzeczywistej przestrzeni geograficznej, kłamliwa i idealizująca praca (nie)pamięci. Miejsca rekonstruowane to niewpisujące się $\mathrm{w}$ plan biografii jednostki przestrzenie przechowywane $\mathrm{w}$ post-pamięci ( $\mathrm{w}$ sensie, jaki temu pojęciu nadała Marianne Hirsch), dokumencie, literaturze, a więc zapośredniczone i przywoływane do życia przez wyobraźnię historyczną i nostalgię za dawnością. Wreszcie skrajny przykład miejsc nieistniejących stanowiłyby miejsca cudze, niepołączone $\mathrm{z}$ tworzącym je podmiotem ani nićmi biograficznymi, ani choćby odległym wspomnieniem, ani nawet post-pamięciową rekonstrukcją. Są to bowiem miejsca, w których po prostu nas-nie-ma. Już powyższa, bardzo szkicowa próba uporządkowania zjawisk będących przedmiotem zainteresowania niniejszego artykułu musi doprowadzić do wniosku, że wszelka klasyfikacja jest niemożliwa. Pozostaje raczej schematyczna typologia, w której poszczególne miejsca przynależą do kilku zaproponowanych typów jednocześnie, a kluczowym zagadnieniem pozostaje nie sama przestrzeń, ale (nie)obecny w niej podmiot i dokonywane przez niego procesy wtórnej semiotyzacji pustki.

1 M. Czermińska, Miejsca autobiograficzne. Propozycja w ramach geopoetyki, „Teksty Drugie” 2011, nr 5 . 
Szczególnie wyraźnie uwidacznia się ten proces w przypadku tekstowych reprezentacji miejsc nieobecnych, czyli tych, których już nie ma, ale istniały wcześniej, a zatem zniszczonych, przemienionych $\mathrm{w}$ dosłowną pustkę, oraz tych, w których nie ma już podmiotu patrzącego i opisującego. To bowiem właśnie figura podmiotu jest najistotniejszą wykładnią nieistnienia miejsca, co też pozwala uniknąć klasyfikacji opartych na naiwnym mimetyzmie lub historiograficznej pedanterii. Przestrzenie nieistniejące są przestrzeniami, w których już nie ma podmiotu, ale był $\mathrm{w}$ nich wcześniej. To zaś uruchamia pracę nostalgii i pamięci, której świadectwem są tak liczne książki dwudziestowiecznej literatury sygnowane nazwiskami Wittlina, Miłosza, Konwickiego i wielu innych poświęcających pióro miejscom, gdzie już ich nie ma i do których nie powrócą. Natomiast tak popularne, zwłaszcza wśród pisarzy miast tzw. Ziem Odzyskanych, ale nie tylko, bo i przecież nowego pokolenia twórców warszawskich itd., literackie strategie post-pamięciowe oraz odtwarzające $z$ zapośredniczenia i wyobraźni wiążą się z miejscami, których opisujący nigdy nie doświadczyli. To zatem podmiot, jako patrzący, jako centrum widzenia i nadawania widzialnemu sensu, jako ośrodek fokalizacji i jednocześnie ośrodek znaczeń, wytwarza przestrzeń i to od jego aktywności zależeć będzie kształt dyskursywnych technik służących tekstowej reprezentacji miejsc nieistniejących i retorycznych figur przestrzennej nieobecności, która przecież dotyczy właśnie podmiotu. Miejsce, w którym podmiot nie jest obecny, staje się dla niego miejscem pustki, którą musi wypełnić tekstem. Wszystkie opisane powyżej rodzaje relacji między podmiotem a miejscem, którego bezpośredniej obecności nie doświadcza, zamknąć można w znanej formule: „Marzący jest tam, gdzie go nie ma, a nie ma go tu, gdzie jest" ${ }^{2}$. Ta romantyczna ontologia okazuje się niebywale trwała, jako że można chyba bez przesady uznać, że najlepsze literackie konstrukcje przestrzeni są zapisem hiatusu, jaki wytwarza się między usytuowaniem mówiącego a usytuowaniem przedmiotu, o którym mówi.

W tym miejscu wypada wprowadzić dygresję związaną z wyobrażeniem spacjalnym, jakim jest pustka, szczególnie zważywszy na jej zauważalną obecność w nowoczesnej myśli humanistycznej, nie tylko literackiej ${ }^{3}$, ale również choćby architektonicznej. Pustka jest zatem kategorią przestrzenną,

2 M. Janion, Marzacy: jest tam, gdzie go nie ma, a nie ma go tu, gdzie jest, w: tejże, Projekt krytyki fantazmatycznej, Warszawa 1991, s. 30.

3 O pustce jako kategorii spacjalnej w literaturze pisał F. Szałasek - Poetyka pustego miejsca. Pejzaże urbanistyczne w katastroficznej science fiction, „Studia Poetica” 2013, nr 1; zob. także D. Czaja, Imiona pustki, w: tegoż, Lekcje ciemności, Wołowiec 2009. 
w której szczególnie silnie do głosu dochodzą procesy utekstawiania, wtórnej semiozy. Jak pisze Heidegger w Sztuce i przestrzeni:

Pustka dość często jawi się jako pewien brak. Pustka uchodzi wówczas za niedostatek wypełnienia pustych i rozciągających się na pewnych odległościach przestrzeni. Przypuszczalnie pustka jest jednakże spokrewniona właśnie z tym, co właściwe miejscu, i dlatego nie jest brakiem, ale wydobywaniem na jaw. Pustka nie jest niczym. Nie jest także brakiem. W plastycznym ucieleśnieniu pustka przejawia się na sposób poszukująco projektującego ustanawiania miejsc ${ }^{4}$.

Pustka zatem znaczy, przypominając o tym, co zostało usunięte, a stanowiło wypełnienie miejsca. Jednocześnie domaga się urzeczywistnienia tkwiących $\mathrm{w}$ niej potencjalności, $\mathrm{w}$ konsekwencji czego - paradoksalnie - kartograficzne białe plamy są punktami najbardziej zatłoczonymi, obfitymi w konkurencyjne narracje, niekończące się znaki, alternatywne historie.

Spacjalna pustka nie może być więc uznawana za negatywny odpowiednik miejsca, jest bowiem pełnoprawnym rodzajem wyodrębnienia przestrzeni, a nawet formą jej specyficznego zagospodarowania. Prowokuje to pytanie o kulturowe, $\mathrm{w}$ tym literackie, formy jej reprezentacji, o szczególnego typu retorykę, która byłaby w stanie zwerbalizować pustkę. Jak pisze w eseju Lublin jest ksiegga Władysław Panas, wprowadzając, co może godne przypomnienia, termin "geopoetyki" na określenie swojej techniki odczytywania miasta ${ }^{5}$ :

Przestrzeń lubelska mówi. To przestrzeń tego, co jest, co istnieje, co wypełnia, oraz przestrzeń miejsc pustych. I w przeciwieństwie do formuły sera szwajcarskiego, gdzie puste miejsce nie daje smaku, w Lublinie miejsca te znaczą. A może nawet mówią jeszcze bardziej niż te wypełnione. Tak się złożyło - i to jest przestrzeni lubelskiej właściwość podstawowa, że właśnie miejsca centralne, o największej nośności semantycznej i semiotycznej są dzisiaj puste ${ }^{6}$.

Trudno byłoby odnaleźć w polskim pejzażu literacko-geograficznym miasta, których opis nie korespondowałby z uwagami Panasa. Polskie teksty miejskie są osnute wokół rzeczywistej, ale też historycznej i dyskursywnej pustki, a fabuły im poświęcone starają się odpowiedzieć na jej wyzwanie. Podmiot próbuje zadomowić się w przestrzeni, której nie doświadczył, wypełnić pustkę obecnością własną i tworzonego przezeń świata postaci, słów, topografii, praktyk przestrzennych.

\footnotetext{
${ }^{4}$ M. Heidegger, Sztuka i przestrzeń, przeł. C. Woźniak, „Principia III” 1991, s. 127-128.

5 W. Panas, Oko Cadyka, w: tegoż, Lublin jest księga, t. 1, Lublin 2008, s. 43.

6 W. Panas, Lublin jest ksiega, w: tegoż, Lublin jest..., s. 147.
} 
W tym celu literatura stosuje szereg strategii tekstowych polegających na jednoczesnym zagadywaniu pustki i jej melancholijnemu eksponowaniu. Te sprzeczne działania spotykają się na płaszczyźnie dyskursu, prowadząc do ciekawych i już na tyle powtarzalnych, że bardzo dobrze rozpoznawanych wśród obiorców, zabiegów, z których analizie poddane tu zostaną z oczywistych względów tylko wybrane. Pogodzenie pustki z tekstem, zapisanie jej ze świadomością, że każdorazowe mnożenie znaków równocześnie tę pustkę unieważnia, wypełnia się już $\mathrm{w}$ tak długowiecznej formule, jaką jest topika ubi sunt? ${ }^{7}$ Doskonale znane $\mathrm{z}$ literackiej tradycji stawianie retorycznych pytań o lokalizację tego, co minęło, odżywa w twórczości memorialno-nostalgicznej, w której łatwo znaleźć można fragmenty takie jak ten, pochodzący z Mojego Lwowa Józefa Wittlina: „Gdzie jesteście ławki lwowskich parków, sczerniałe od starości i deszczu, chropawe i popękane jak kora średniowiecznych, oliwnych pinii? [...]. Gdzie jesteście dzisiaj?" 8 . Pytanie ubi sunt stanowi jedną z podstawowych figur nieobecności wykorzystywanych w ramach retoryki zapisywania pustki. $\mathrm{W}$ tej dobrze rozpoznanej formule spotykają się dwa niezwykle istotne dla omawianej poetyki parametry - kategoria przestrzenna oraz antropologiczna. W jednej frazie równocześnie przywołane zostają dawna obecność i dzisiejszy brak, które łączy to samo miejsce, punkt bycia i nieobecności zarazem. Zastosowanie formy pytającej podkreśla natomiast niepewność podmiotu co do efektów procesu przestrzennej percepcji. Niepewność ta wiąże się z niedostępnością dla zmysłu wzroku tego, co wypełnia pustkę.

Analiza sposobów konstruowania figur nieobecności i tworzenia na ich podstawie retoryki pustki w literaturze XX i XXI wieku prowadzi do wniosku, że w bardzo dużej mierze przypomina ona - na płaszczyźnie retoryczności i figuratywności właśnie - tradycyjne obrazowanie wanitatywne. Deskrypcja miejsc nieistniejących cechowałaby się zatem częstym występowaniem toposu ubi sunt i vanitas, typowymi dla écriture mélancolique środkami stylistycznymi, jak enumeracja (zwłaszcza nadreprezentacja wyliczeń toponimów), pytania retoryczne, przeczenia, elipsy, cytaty ${ }^{9}$, czy genologiczne nawiązania do konwencji elegijnej i funeralnej. Jaskrawym przykładem dwudziestowiecznej realizacji tradycyjnej estetyki melancholijnej jest na przykład

\footnotetext{
7 Zob. S. Skwarczyńska, Topos "Ubi sunt qui ante nos fuerunt” oraz styczne z nim formacje treściowo-formalne w poezji europejskiego kręgu kulturowego, w: tejże, W orbicie literatury, teatru, kultury naukowej, Warszawa 1985.

8 J. Wittlin, Mój Lwów, Warszawa 1991, s. 12.

9 Zob. M. Bieńczyk, Melancholia. O tych, co nigdy nie odnajda straty, Warszawa 2012; T. Sławek, Saturniczny pątnik. Robert Burton i jego "Anatomia melancholii", "Literatura na Świecie” 1995, nr 3.
} 
Elegia miasteczek żydowskich Antoniego Słonimskiego: „Nie masz już, nie masz w Polsce żydowskich miasteczek" - rozpoczyna swój lament podmiot liryczny, przez powtórzenie początkowej frazy potwierdzając diagnozę braku, który obejmuje przestrzenie tytułowych miasteczek - „W Hrubieszowie, Karczewie, Brodach, Falenicy" - ujętych, co znamienne, w wyliczenie właśnie, które staje się sporządzaniem listy strat i jednocześnie manifestem ocalającej mocy imienia własnego, które jest schronieniem dla sensu i dawnej obecności. Dalsza część elegijnego przywoływania nieistniejących miejsc obfituje w słowa-klucze znamienne dala retoryki pustki:

Próżno byś szukał w oknach zapalonych świeczek,

$[\ldots]$

Znikły resztki ostatnie, żydowskie łachmany,

Krew piaskiem przysypano, ślady uprzątnięto

I wapnem sinym czysto wybielono ściany

[...]

Nie odnajdą dwu złotych księżyców Chagala.

Te księżyce nad inną już chodzą planetą,

Odfrunęły spłoszone milczeniem ponurym.

Już nie ma tych miasteczek, gdzie szewc był poetą,

[...]

Nie ma już tych miasteczek, gdzie biblijne pieśni

Wiatr łączył z polską piosnką i słowiańskim żalem,

[...]

Nie ma już tych miasteczek, przeminęły cieniem ${ }^{10}$.

Czasownikom wskazującym na nieistnienie i znikanie towarzyszy cytat - intersemiotyczne odwołanie do Chagalla (a więc również artysty zaniku i braku) - oraz, co znamienne, rzeczowniki, które nazywają nieokreślony status przestrzeni. „Resztki”, „ślady”, „milczenie”, „cień" pojawiają się tutaj na prawach derridiańskich widm, będąc językowym opracowaniem owej resztki, tego, co pozostaje po nieobecnym zmarłym, formy, w jakiej żyje on $\mathrm{w}$ podmiocie odgrywającym proces żałoby. Ta żydowska w przypadku omawianej Elegii... hauntologia oddaje niejednoznaczny status nieobecnego, którego jednocześnie nie ma i który istnieje w doświadczającym go podmiocie. $W$ miejsce braku pozostaje wiersz, ciąg zrytmizowanych signifiants, a

10 A. Słonimski, Elegia miasteczek żydowskich, w: tegoż, Poezje zebrane, Warszawa 1964, s. 495, [podkr. - K.Sz.]. 
znak, który wszak odracza obecność, daje się pomyśleć jedynie $w$ odniesieniu do obecności, którą odracza, i ze względu na odroczoną obecność, do której odzyskania dąży. Zgodnie z tą klasyczną semiologią podstawienie znaku w miejsce samej rzeczy ma charakter tyleż wtórny co tymczasowy: wtórny względem pierwotnej a utraconej obecności, od której znak miałby się wywodzić; tymczasowy wobec tej ostatecznej a nieobecnej obecności, w stosunku do której znak znajdowałby się $\mathrm{w}$ relacji zapośredniczenia ${ }^{11}$.

Miejsca nieistniejące rozrastają się, anektując coraz to nowe przestrzenie współczesnej literatury. Przedmiotem zainteresowania jest nie tylko ich status i techniki deskrypcji, ale i sam proces zanikania miejsc, co dokumentuje literatura niefikcjonalna ${ }^{12}$. Miejscom nieistniejącym w pozatekstowej rzeczywistości i obecnym $\mathrm{w}$ tekście na mocy nostalgii, pamięci, post-pamięci czy mitu towarzyszą te, które stawiają podmiot przed pytaniem o prawdopodobieństwo i przeznaczenie. Dzieje się tak choćby w liryku Dworzec Wisławy Szymborskiej, w którym: „Odbyło się nawet umówione spotkanie. Poza zasięgiem naszej obecności"13. Tytułowy dworzec to miejsce istniejące $\mathrm{w}$ rzeczywistości, lecz pozbawione obecności podmiotu wypowiadającego, a więc miejsce-w-którym-mnie-nie-ma. „Uchodził w tłumie do wyjścia brak mojej osoby"14 - podmiot liryczny diagnozuje $w$ ten sposób nieistnienie opisywanego, brak osoby jest brakiem patrzącego, a więc też i stwarzanego pod jego spojrzeniem miejsca. Pustkę konstruuje Szymborska w poetyce apofatycznej, w milczeniu uzyskiwanym dzięki asyndetonicznej składni wiersza, w nagromadzeniu słów z przedrostkiem nie-, w negacji i wypróbowywaniu możliwości, które są niby-istnieniem, ale nie pełną obecnością.

Kolejną cechą łączącą literackie deskrypcje pustki byłaby dominacja w konstruowaniu tekstowego ośrodka fokalizacji zmysłu wzroku. Raz jeszcze powołać się trzeba na obserwację Panasa, który pisał:

Niewidzialny, bo niematerialny, jest sens. [...]. Można przywołać tu i takie skojarzenia wzrokowe: nawias i elipsa. Obydwie figury są figurami nieobecności, lecz nie pustki, ponieważ natarczywie stawiają pytanie o to, co zostało wzięte

11 J. Derrida, Różnia, przeł. J. Margański, w: tegoż, Marginesy filozofii, przeł. A. Dziadek, J. Margański, P. Pieniążek, Warszawa 2002, s. 36.

12 Zob. choćby S. Aleksijewicz, Czarnobylska modlitwa: kronika przyszłości, przeł. J. Czech, Wołowiec 2012; Ch. Leduff, Detroit: sekcja zwłok Ameryki, przeł. I. Noszczyk, Wołowiec 2015; F. Springer, Miedzianka: historia znikania, Wołowiec 2011.

13 W. Szymborska, Dworzec, w: tejże, Poezje, przedmowa J. Kwiatkowski, Warszawa 1970, s. 111.

14 Tamże, s. 110. 
w nawias, co uległo eliptycznemu pominięciu. I obydwie, a zwłaszcza elipsa, zakreślając granice nieobecności, odpowiadają natychmiast: to, co było w środku, to, co było tutaj, to, o co uzupełnia się ta całość. W środku był Widzący, to jego miejsce zostało wzięte $\mathrm{w}$ nawias i eliptycznie wyeliminowane ${ }^{15}$.

Do repertuaru retoryki miejskiej, w której de Certeau wyróżniał, jak wiadomo, figury synekdochy i asyndetonu, Panas dodaje nawias i elipsę, pozostając w zasadzie bliskim tak odrębnemu w swej metodologii myśleniu autora Praktyk przestrzennych. Miasto na mocy pars pro toto prezentuje części w zamian za nieistniejące całości, asyndeton - jak pisze de Certeau - wprowadza nieobecność do przestrzennego continuum, zachowując z niego tylko wybrane fragmenty albo szczątki ${ }^{16}$. Panas proponuje odróżnić nieobecność od pustki. Ta pierwsza zakłada bowiem wcześniejsze istnienie, pierwotne wypełnienie oglądanego miejsca.

W lewym górnym rogu widać szarą, niekształtną plamę. Nam, stojącym na rynku, wiadomo, że jest to mała czarnowłosa dziewczynka. Ale my - naoczni świadkowie faktów, które zarejestrowała fotografia - wiemy więcej niż ci, którzy oglądają album pół wieku później. [...] Pan Baum wchodzi do sklepu i niknie w jego ciemnawym wnętrzu. Przez chwilę za szybą widzimy na tle półek z tkaninami jego głowę ${ }^{17}$.

Fragment Zagłady Piotra Szewca stanowi niezwykle ciekawy przykład literackiego konstruowania pustki, nie tylko ze względu na mistrzostwo prozy autora, ale też wyłaniającą się z jego deskrypcji swoistą fenomenologię pustki. Powołując się na rozróżnienie Panasa, należałoby pielęgnować semantyczną różnicę między pojęciem pustki i nieobecności. Tyle że podział ten okazuje się nieprzydatny przy analizie Zagłady. Istnienie (nawet przeszłe) opisywanej przestrzeni jest wciąż przez narratora podawane w wątpliwość. W końcu

To mało zbadany czas zaprzeszły, znaki zapytania stawiane przez kolejną współczesność. Jak dym rozwiany przez gołębie, one i splot im podobnych faktów, okoliczności, będą, na podobieństwo spalonego papieru, rozrzuconym bezładnie $\mathrm{w}$ czasie pyłem ${ }^{18}$.

Trudno tutaj odróżnić nieobecność od pustki, Szewc unieważnia pytania o ontologię, wprowadzając kolejne zapośredniczenia - fotografię, szkło

\footnotetext{
15 W. Panas, Jeździec niebieski. Szkice i fragmenty lubelskie, w: tegoż, Lublin jest..., s. 44.

16 M. de Certeau, Wynaleźć codzienność. Sztuki działania, przeł. K. Thiel-Jańczuk, Kraków 2008, s. 102.

17 P. Szewc, Zagłada, Kraków 2003, s. 9-13.

18 Tamże, s. 7.
} 
wystawowe - i sięgając do wspomnianego już rezerwuaru wanitatywnych motywów - dym, płonący papier. Narrator powieści pyta jednak o to, co zostało pominięte $\mathrm{w}$ elipsie, rekonstruuje pole widzenia, co $\mathrm{w}$ Zagładzie podlega wzmocnieniu poprzez tematyzację punktu widzenia - podkreślanie, że opowiadający jest jednocześnie patrzącym, że zajmuje tę samą przestrzeń co nieistniejący dziś rynek. Taka konstrukcja służy próbie przezwyciężenia eliptycznego pominięcia, odtworzenia tego, co było, i zostawiło ślad w składni. Najważniejsza jest tutaj jednak próba ponownego umiejscowienia oka/podmiotu wewnątrz nawiasu - stąd obecność czasowników wskazujących na patrzenie i na usytuowanie względem nieistniejącego rynku. Jednocześnie jednak Szewc nie pozwala dojść do głosu poznawczemu optymizmowi i tę restytucję podmiotowości znosi, pytając o ontologię opisywanego świata i wyzyskując właściwości figury fotografii jako równocześnie widzenia i nieobecności.

Elipsa nie pozwala doświadczyć nieobecnego w sposób bezpośredni, ale umożliwia jego przestrzenne zlokalizowanie. Nawias nie należy do tekstu głównego, lecz nie sposób go pominąć. To, co ulega eliptycznemu pominięciu, jest konieczne dla zrozumienia tego, co w tekście pozostało. Na tej zasadzie opiera się kompozycja i model odczytania większości utworów powstałych w ramach strategii post-pamięciowych i odtwarzających przestrzeń, która nie była przedmiotem doświadczenia autora, przykładem choćby $\mathrm{Ha}$ nemann Stefana Chwina:

Günter Schultz biegł do szkoły po bruku ułożonym w rybią łuskę, Bierensteinowie idąc do teatru potykali się o szyny tramwaju jadącego przez Langer Markt, syn pani Peltz cienkim pędzelkiem malował na wystawowej szybie kawiarni przy Breitgasse 13 złoty napis "Caffe«, lecz szkło drwiło z każdego ruchu jego ręki szyderczymi odblaskami słońca, bo wiedziało już, że gdy nadejdzie czas, przeźroczysta tafla rozpryśnie się w tysiące iskier niczym kruchy lód ${ }^{19}$.

Tekstowe działanie powyższego fragmentu oparte zostało na zasadzie asyndetonu - symultaniczne ukazanie działań postaci ma odwzorowywać istnienie fragmentów, oraz synekdochy, która staje się dominantą kompozycyjną cytowanego rozdziału pełnego opisów poniemieckich, pojedynczych rzeczy zastępujących na mocy metonimii swoich właścicieli, a na mocy pars pro toto właśnie - nieistniejący świat Gdańska okresu Wolnego Miasta i drugiej wojny światowej. Tym, co jednak najsilniej wiąże Hanemanna z poetyką braku, jest spojrzenie na miasto, w którym uwidaczniają się elipsy i nawiasy, to, co usunięte, zapomniane, nieobecne, i co właśnie staje się tematem książki.

19 S. Chwin, Hanemann, Gdańsk 1995, s. 27. 
Książki, która jest reprezentatywna dla bardzo już licznej grupy tekstów odchodzących od tego, co widziane, ku temu, co zostało eliptycznie pominięte. $\mathrm{O}$ ile twórcy sytuujący się $\mathrm{w}$ ramach strategii pamięciowej i nostalgicznej, jak Wittlin, przechodzą od wspomnienia wypełnionej przestrzeni przeszłości do konstatacji pustki teraźniejszości, co spełnia się $\mathrm{w}$ formule pytania $u b i$ sunt i omówionej poetyce wanitatywnej, w skupieniu na tym, co elipsa wymazuje; o tyle pisarze rekonstruujący historię miejsca z zapośredniczeń lub post-pamięci dokonują ruchu $\mathrm{w}$ odwrotnym kierunku - widząc brak, próbują uzupełnić eliptyczną frazę, zrekonstruować pominięte fragmenty. Jednocześnie jednak są świadomi beznadziejności starań, Chwin w nawias bierze nie historię, która stanowi wypełnienie książki, ale teraźniejszą pustkę po przeszłości. Dzisiejsza perspektywa ujawnia się dyskretnie w obrazie szkła, na którym bohater zapisuje ślady swojej obecności, nieświadom czekającej i jego, i szkło katastrofy.

Strategie utekstawiania pustki nie sprowadzają się jednak wyłącznie do wyliczenia elementów przeszłości, choć akurat enumeracja pozostaje jedną z ważniejszych figur melancholijnego myślenia o przeszłości. Ograniczając się tutaj jedynie do metafor miejsca, nietrudno wskazać wyjątkową żywotność dyskursywnych figur mapy, planu miasta oraz przestrzeni archiwum, muzeum czy biblioteki. Mapa i plan miasta organizują nierzadko topograficzną post-pamięć i rekonstrukcję, wspomniany już tekst Hanemanna zaopatrzony został w postscriptum w postaci wskazania dzisiejszych odpowiedników dla użytych toponimów niemieckich. Onomastyka staje się tutaj wypełnieniem elipsy, nazwa ma bowiem przywołać nieistniejący desygnat, jakim jest przestrzeń dawnego miasta. Jednocześnie, poprzez odwołanie do współczesnych lokalizacji, zakreśla granice nieobecności, wskazuje miejsce braku, które można odnaleźć także na współczesnej mapie Gdańska.

Pozostając przy twórczości Chwina, zauważyć należy jeszcze jedną, charakterystyczną dla twórców melancholijnych przestrzeni, właściwość, która polega na zapełnianiu pustki przez metafikcję. Okładkę jednej z jego powieści, Panny Ferbelin ${ }^{20}$, konstruują komentarze, fragmenty recenzji podpisane imionami Manfreda Hanemanna czy Esther Simmel i pochodzące rzekomo z takich periodyków jak „Nowiny Gdańskie” czy „Danziger Beobachter". Rzecz jasna, są to nazwiska osób będących bohaterami innych powieści Chwina, a ten autotematyczny i auto-intertekstualny ruch wskazuje na kolejną figurę retoryki pustki, jaką jest metapismo. Przestrzenny brak prowadzi ku tekstowi, ku rekonstrukcji $\mathrm{w}$ dyskursie, stąd popularność $\mathrm{w}$ tego

20 S. Chwin, Panna Ferbelin, Gdańsk 2011, IV strona okładki. 
typu literaturze metafor pamięci organizujących nostalgiczną wyobraźnię historyczną, takich jak archiwa, albumy fotografii, antykwariaty, które stają się zasadą kompozycyjną tekstowych found footage, historycznych narracji budowanych ze strzępów dokumentów, kronik, relacji i wyobraźni autora. Pustka domaga się reprezentacji, ale ta nie może stać się bezpośrednia - jak bowiem pokazać to, czego nie ma - pomiot, przyzwyczajony do empirycznej weryfikacji, zwraca się zatem w stronę tego, co stanowiłoby dowód wcześniejszego istnienia, przykład czyjejś uprzedniej obecności, stąd popularność metafor pisma (takich jak historie miejskie jako archiwum czy miasto jako palimpsest) i metafor wzroku (fotografia - jak w analizowanym przykładzie Szewca - czy plan miasta $\mathrm{w}$ roli obrazów (nie)widzialnej przeszłości, czy też opisanego przez autora Zagłady czasu zaprzeszłego).

Tym samym powrócić wypada do pytania o figurę nieobecności i podmiotowy aspekt tekstualizacji przestrzeni pustki. Panas pisze, że elipsa ukazuje puste miejsce po widzącym, po tym, który stanowił ośrodek percepcji. Wittlin w kontekście lwowskich ławek, które pojawiły się w poprzednim cytacie, pisze: „Nie rozczulajmy się nad ławkami, bo okaże się, że nie nad nimi, lecz nad sobą się rozczulamy" ${ }^{21}$. Pustka nie istnieje w sposób obiektywny, jest każdorazowo wynikiem procesu szczególnego typu utekstowienia przestrzeni, rezultatem zestawienia teraźniejszego z wyobrażeniem minionego. Odkrycie pustki spacjalnej łączy się z rozpoznaniem pustki w sobie. To zresztą jedno ze znanych prawideł antropologii melancholijnej. Strata, którą to doświadczenie zakłada, odbywa się w wewnętrznej przestrzeni podmiotu, ale jednocześnie jest przez ów podmiot jako centrum obserwacji rzutowana $\mathrm{w}$ miejsca zewnętrzne. Te pod melancholijnym wzrokiem ${ }^{22}$ pustoszeją, zanikają, cichną, ludzka obecność zmienia się $\mathrm{w}$ jej metonimiczne i reifikujące reprezentacje (vide rola przedmiotów u Chwina, pomników u Wittlina), a tak boleśnie odczuwany wymiar temporalny przechodzi modyfikację w przestrzenny. Melancholijny wzrok wytwarza pustkę, nieobecność dotyczy patrzącego. Wittlin pisze o Lwowie, w którym już go nie ma, o tym samym mieście Zagajewski stworzy poemat $w$ tytule już zawierający niedokonany aspekt czasownika. Miłosz napisze $W$ mojej ojczyźnie, do której nie wrócę, tworząc liryczną deskrypcję miejsc pustych, w tym sensie, w jakim pustką jest to, na co podmiot nie patrzy. "Ja" liryczne, konstruując przestrzenne figury liryczne, wskazuje na swój udział w owym geście tworzenia:

21 J. Wittlin, Mój Lwów, s. 13.

22 O powiązaniu melancholii ze spojrzeniem i brakiem pisze P. Śniedziewski (P. Śniedziewski, Melancholijne spojrzenie, Kraków 2011). 
W mojej ojczyźnie, do której nie wrócę,

Jest takie leśne jezioro ogromne,

Chmury szerokie, rozdarte, cudowne

Pamiętam, kiedy wzrok za siebie rzucę ${ }^{23}$.

Po raz kolejny pojawia się rola spojrzenia w konstruowaniu pustki. Tego, co nie istnieje, nie sposób zobaczyć, chyba że „rzuci się" wzrok za siebie, czyli zamieni pracę oka na pracę pamięci. Pustka jest zawsze wyzwaniem rzuconym wzrokocentryzmowi. Chwin konstruuje Gdańsk, który nigdy nie stał się przedmiotem jego doświadczenia, nieobecność w Hanemannie nie dotyczy bohaterów książki, lecz instancji nadrzędnej wobec świata przedstawionego, owego melancholijnego oka, które widzi proces rozpadu, opustoszania pełnej jeszcze w momencie opowiadania przestrzeni. "Już tutaj, w konstrukcji pola widzenia, strata i zanik wydają się podstawowe; rzeczywistość to proces usuwania tego, co zakłóciło puste i nieokreślone trwanie. Rządzi nią impuls odejmowania" ${ }^{24}$, wytwarzania pustki wobec nieobecności patrzącego.

Projektowana retoryka pustki, czyli sposoby utekstawiania przestrzeni naznaczonych nieobecnością podmiotu percypującego, pozostaje w związku z koncepcjami spacjalnymi, które już temat braku podejmowały i z których rzecz jasna wskazaniu ulegnie ledwie kilka. Zresztą wszystkie one mają wspólne źródło inspiracji, jakim jest koncepcja miejsc pamięci Pierre'a Nora. I tak, w typologii miejsc autobiograficznych autorstwa Małgorzaty Czermińskiej znajdują się te wyobrażone, czyli utracone często $\mathrm{w}$ wyniku tragedii historycznej, lecz obecne w pamięci rodzinnej i opowieści. W taką charakterystykę można by więc wpisać Lwów Zagajewskiego z całym kompleksem topograficznej wyobraźni związanej z budowaniem fantazmatu miasta jako umiejscowienia własnej genealogii. W przypadku Wittlina i Miłosza natomiast miejsce wyobrażone łączy się ze wspominanym, jakim byłaby według przedstawianej typologii przestrzeń dzieciństwa rekonstruowana poprzez pracę pamięci. Trudniej dopasować tutaj Gdańsk Chwina, jako że uwagi dotyczą miejsc autobiograficznych i też tego typu literatury, lecz przecież przestrzeń Hanemanna rodzi się z autobiograficznego doświadczenia jej autora $\mathrm{w}$ spotkaniu $\mathrm{z}$ miastem podziurawionym.

Ciekawą koncepcję formułuje Monika Sznajderman, proponując - analogicznie do kategorii post-pamięci - mówić o post-miejscu, czyli - jak pisze

\footnotetext{
${ }^{23}$ Cz. Miłosz, W mojej ojczyźnie, w: tegoż, Wiersze, t. 1, Kraków-Wrocław 1984, s. 67.

24 M. Bieńczyk, „Wszystko w świecie tracić" (O „Marii” Antoniego Malczewskiego), w: tegoż, Oczy Dürera. O melancholii romantycznej, Warszawa 2002, s. 39.
} 
[w] mojej całkowicie prywatnej terminologii, to miejsce, które wskutek traumatycznych wydarzeń opustoszało, tak zewnętrznie, jak i w swojej wewnętrznej istocie, które umarło i stało się nie-miejscem. I które teraz dzięki mechanizmom post-pamięci ożywa, ale [...] w sposób zastępczy i przywłaszczony; ożywa, zyskując nową egzystencję na poziomie symbolicznym, i pozbywa się statusu nie-miejsca, nie stając się wszakże ponownie w pełni miejscem ${ }^{25}$.

Sznajderman wprowadza kategorię post-miejsca, by za jej pomocą odczytać - co symptomatyczne - historię rodzinną zaklętą w przestrzeniach widocznych na fotografiach, zrekonstruować ją z domysłów i interpretacji. Tak jak miejsca autobiograficzne wiążą się z omawianym wcześniej nurtem memorialno-nostalgicznym w literaturze dwudziestowiecznej, konstatującym pustkę, tak post-miejsca byłyby spacjalną odpowiedzią na narracje post-pamięciowo-zapośredniczone, pustką zaniepokojone i próbujące ją przezwyciężyć. Sznajderman blisko zresztą do jeszcze innej koncepcji zajmującej się przestrzenią w sposób, chciałoby się rzec, apofatyczny, jak wymaga tego kategoria pustki. Chodziłoby tutaj o coraz częściej pojawiające się propozycje nazewnicze wobec tak zwanych nie-miejsc pamięci ${ }^{26}$, inspirowane bądź to Sebaldem, bądź - jak choćby w opracowaniu Romy Sendyki, która formułuje konkurencyjny termin "pryzmy” 27 - wypowiedziami Claude'a Lanzmanna. Nie-miejsca pamięci byłyby więc - w odróżnieniu od tych opisanych przez Nora - punktami, w których żadna ze społeczności nie obsadza swoich kulturowych rytuałów, ale też żaden podmiot nie otacza symboliczną aurą ${ }^{28}$.

$\mathrm{Z}$ ujęciem urbanistycznych nie-miejsc dyskutuje między innymi Dolores Hayden, wskazując, że wzrastające zainteresowanie zanikaniem przestrzeni nie może zastąpić jej analizy, stąd wywodzi się jej sugestia, by przedmiotem badania uczynić „złe miejsca” (bad places), czyli te, które zostały dotknięte stratą, zmianą znaczenia itd. ${ }^{29}$ Namysł nad miejskimi pustkami nie jest zjawiskiem nowym, a znajduje bardzo silne umotywowanie historyczne $\mathrm{w}$ przemianach architektury i praktyk spacjalnych, jakie dokonały się po traumie wojennej. Stąd też coraz liczniejsze propozycje terminologiczne i metodologiczne związane z eksplorowaniem pustki. Pryzmy, nie-miejsca pamięci

\footnotetext{
25 M. Sznajderman, Przerwy w pamięci. Historia rodzinna, w: Inne przestrzenie, inne miejsca. Mapy i terytoria, wyb., red. i wstęp D. Czaja, Wołowiec 2013, s. 301.

26 Zob. R. Sendyka, Pryzma - zrozumieć nie-miejsce pamięci, w: Inne przestrzenie...

27 Tamże.

28 Tamże, s. 279.

29 Zob. D. Hayden, The Power of Places, Cambridge 1996, s. 18.
} 
czy złe miejsca stanowiłyby komponenty „miejskiej estetyki nieobecności” ${ }^{30}$, by posłużyć się terminem Shustermana. Zresztą sam autor Estetyki pragmatycznej... widzi w nieobecności ważne znaczące urbanistycznego tekstu, budujące właśnie poprzez brak bogatą narrację ${ }^{31}$. Podobne rozważania odnaleźć można także w pracach Andreasa Huyssena, analizującego fenomenologię pustki w powiązaniu z berlińską przestrzenią traumy ${ }^{32}$. W kontekście Berlina nie sposób natomiast nie wspomnieć o architektonicznych manifestach i ich teoretycznych podbudowaniach w postaci tekstów autorstwa Daniela Libeskinda, który wyznaje: „Ahistoryczny wymiar pustki zawsze mnie intrygował. Oczywiście pustka ma historyczną trajektorię, trajektorię fatalności. Jednakże jest coś w pustce, co nie zgadza się z historią pozytywistyczną" ${ }^{\prime 3}$. Ten bardzo lapidarny przegląd analiz miejskiej pustki można by długo kontynuować ${ }^{34}$, co wskazuje tylko na przewartościowanie, jakie dokonało się $\mathrm{w}$ ramach badań przestrzennych, zmianę kierunku spacjalnych zainteresowań z miejsc obecnych ku nieistniejącym.

Libeskind stwierdza, że pustka jest ahistoryczna, gdyż nie wpisuje się w pozytywistyczną opowieść o dziejach. Jednak historia pustki jest możliwa, byłyby to zatem dzieje miejsca pozbawione patrzącego, pejzaży pozbawionych oka. I w takim rozumieniu miejsca nieistniejące stanowią skrajny przykład retoryki pustki. Skrajny, bo interesujące mnie miejsca, w których podmiotu już nie ma, lub nigdy nie było, stanowią jednak przykład konstruowania się pustki w kadrze melancholijnego spojrzenia, dla którego podstawowymi figurami są antynomie obecności i nieobecności, pominiętego i eksponowanego, a podstawowymi formułami pytania o lokalizację tego,

\footnotetext{
30 R. Shusterman, O sztuce i życiu: od poetyki hip-hopu do filozofii somatycznej, wyb., oprac. i przeł. W. Małecki, Wrocław 2007.

31 Shusterman analizuje to zjawisko na przykładzie Muru Berlińskiego: „Nieobecny teraz mur dzielący Wschód i Zachód pozostaje na wiele sposobów porządkującą zasadą tego zjednoczonego miasta, tak samo jak oddzielone miasta - Berlin Wschodni i Zachodni - były w istocie definiowane przez swe przeciwstawne, nieobecne części" [R. Shusterman, O sztuce..., s. 149].

32 A. Huyssen, Berlińskie pustki, przeł. J. Mostowska, w: Pamięć zbiorowa i kulturowa. Wspótczesna perspektywa niemiecka, red. M. Saryusz-Wolska, Kraków 2009.

33 D. Libeskind, Traces of the Unborn, za: E. Domańska, "Niechaj umarli grzebia żywych". Monumentalna przeciw-Historia Daniela Libeskinda, „Teksty Drugie” 2004, nr 1-2, s. 93.

$34 \mathrm{O}$ roli pustki w nowoczesnej geopoetyce zob. E. Rewers, Post-polis. Wstęp do filozofii ponowoczesnego miasta, Kraków 2005, rozdz. Ontologia śladów i pustek: w stronę miasta-palimpsestu, s. 21-70; R. Sendyka, Pryzma - zrozumieć nie-miejsce pamięci (non-lieux de mémoire), "Teksty Drugie” 2013, nr 1-2; taż, Robinson w nie-miejscach pamięci, „Konteksty. Polska Sztuka Ludowa” 2013, nr 2. Zob. też J. Kociatkiewicz, M. Kostera, Antropologia pustych przestrzeni, w: Pisanie miasta czytanie miasta, red. A. Zeidler-Janiszewska, Poznań 1997.
} 
co minęło, wreszcie o odczucie wzniosłości, jakie wytwarza się w kontakcie $\mathrm{z}$ pustką - w romantycznej estetyce spełniało się ono w figurze ruiny, $\mathrm{w}$ ponowoczesnej wersji ruiną staje się miasto ${ }^{35}$.

\section{Figures of Absence / Rhetoric of Emptiness}

\section{Summary}

The paper analyzes the figures of absence, connected with both the rhetoric of emptiness and poetics of disappearance. It is moreover an attempt to classify the discursive techniques that aim to represent the textual "gone" (places that no longer exist, were destroyed, and those in which the subject is present no more). Attention is also devoted to performative dimension of writing, which produces the emptiness and, in this production, fills the void and introduces it into cultural network. The article explores literary examples from the 20th and 21st centuries.

Keywords: rhetoric, poetics, discursive techniques, performative turn

35 O romantycznej figurze ruiny zob. G. Królikiewicz, Terytorium ruin: ruina jako obraz i temat romantyczny, Kraków 1993, o jej urbanistycznej, nowoczesnej wersji - M. Nieszczerzewska, Narracje miejskiej wyobraźni, Poznań 2009. 